\title{
Chemical Standardization of Thetran Vithai Kutinir Chooranam - An Antidiabetic Siddha Polyherbal Formulation
}

\author{
Elankani $\mathbf{P}^{1, *}$, Murugammal S ${ }^{2}$, Shakila R2, Pitchiahkumar $\mathbf{M}^{3}$, N.Kabilan ${ }^{4}$
}

Elankani $\mathrm{P}^{1, *}$, Murugammal $\mathrm{S}^{2}$ Shakila $\mathrm{R}^{2}$, Pitchiahkumar $\mathrm{M}^{3}$, N.Kabilan ${ }^{4}$

'Research Officer (Siddha), Siddha Central Research Unit, Palayamkottai, Tirunelveli 627002, INDIA.

${ }^{2}$ Department of Chemistry, Siddha Central Research Institute, Arignar Anna Hospital Campus, Arumbakkam, Chennai-606106, INDIA.

${ }^{3}$ State Drug Licence Authority (IM), Office of State Drug Licence Authority (IM), Arignar Anna Hospital for Indian Medicine Campus Annexes, Arumbakkam, Chennai-606106, INDIA.

${ }^{4}$ Dr.M.G.R Medical University, Guindy, Chennai-600032.

\section{Correspondence}

\section{P. Elankani}

Research Officer (Siddha)-Scientist

II Siddha Clinical Research Unit,

Palayamkottai, Tirunelveli- 627002, Tamil

Nadu, INDIA.

E-mail: pookanisiddh@gmail.com

History

- Submission Date: 05-05-2019;

- Review completed: 19-06-2019;

- Accepted Date: 12-07-2019.

\section{DOI : 10.5530/pj.2019.11.173}

Article Available online

http://www.phcogj.com/v11/i5

\section{Copyright}

(C) 2019 Phcogj.Com. This is an openaccess article distributed under the terms of the Creative Commons Attribution 4.0 International license.

\begin{abstract}
Introduction: Belief of general public on herbal drugs led to the stable growth of herbal drug industry thereby necessitated the standardization of herbal drugs and pharmacopoeial standards for their quality control. Aims: Thetran Vithai Kutinir Chooranam (TVKC) is a Siddha polyherbal formulation used for type II diabetes. Aim of the present study is to standardize the drug chemically. Methods and Material: Drug was prepared as per the literature, stored in air tight container and subjected to preliminary phytochemical analysis, physico-chemical, thin layer chromatographic photo documentation, high performance thin layer chromatographic finger printing along with chemical markers such as emodin, chrysophanol and gallic acid, quantitative assay of marker compounds, heavy metal analysis, pesticide residue, aflatoxin and microbial load analysis. Results: The results revealed that the drug contains emodin in minor quantity and gallic acid in considerable quantity. The drug is free from microbial, heavy metal contaminations, aflatoxin and pesticide residues. Conclusions: The derived results could serve as a ready reference for quality control assessment of the drug.

Key words: Thetranvithai, Katukkai, Vilam Pisin Alkaloid, Anthraquinone.

Key Messages: The present study of chemical standardization of Thetran Vithai Kutinir Chooranam, an antidiabetic polyherbal Siddha formulation leads to the quality control standards in terms of preliminary phytochemiicals, physico-chemical parameters, TLC identification, HPTLC finger print profiles and quantification of gallic acid which may be useful for the quality check of commercial drug in future
\end{abstract}

\section{INTRODUCTION}

Type II diabetes is an embryonic disease of life style disorders. Many herbal medicines of proprietary nature and classical Siddha/Ayurveda formulations are sold in the market for type II diabetes. It is very inopportune to say that none of these medicines are having pharmacopoeial standards for quality control check and authenticity substantiation. Standardization of any herbal drug has become indispensable for framing out the quality standards of the herbal drug. Physicochemical parameters, qualitative and quantitative thin layer chromatographic studies play vital role for comparing any geological variation, seasonal variation and maturity of the plants used in the formulation. TVKC comprises of four herbal ingredients (Figure 1), viz., Strychnos potatorum Linn. seed (Thetran vithai), Terminalia chebula Retz fruit rind (Katukkai thol), Cassia auriculata Linn. seed (Aavaaram vithai) and Limonia accidisima L. gum (Vilam pisin) in equal composition. Four gram of the drug is added with $240 \mathrm{ml}$ of water, boiled, filtered and reduced to $60 \mathrm{ml}$. This $60 \mathrm{ml}$ is prescribed for diabetic adults twice a day. ${ }^{1}$ The monographs on T. chebula, ${ }^{2}$ Strychnos potatorum ${ }^{3}$ are available. The combinations of above four drugs, TVKC is not reported for standardization, hence authors aimed to standardize.

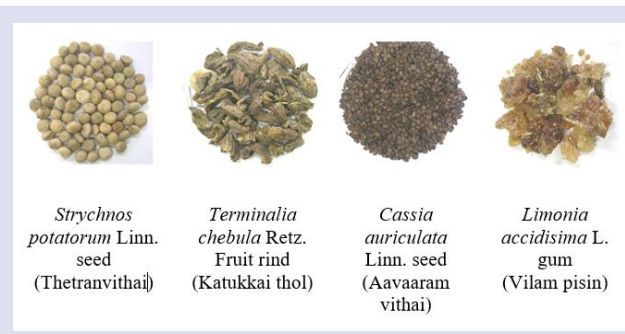

Figure 1: Ingredients of TVKC.

\section{MATERIALS AND METHODS}

Plants Strychnos potatorum Linn. seed and Terminalia chebula Retz fruit were procured from local crude drug market, authenticated by Research Officer (Pharmacognosy) of this Institute. Cassia auriculata Linn. seed and Limonia accidisima L. gum were collected and authenticated by Dr. Padma Sorna Subramanium, Research Officer (Botany), Survey of Medicinal Plants Garden, Mettur, Tamil Nadu. The specimen of all samples were deposited in the Institute.

\section{Purification of drugs}

Strychnos potatorum Linn. seeds was soaked in cow's milk for 24 minutes, washed and shade dried for use Terminalia chebula fruits were broken and seeds were removed. ${ }^{4}$ 


\section{Preparation of TVKC}

All the ingredients were powdered separately, taken in the equal ratio and mixed well, stored in airtight container for all the studies.

\section{Chemicals and solvents}

All the solvents used for this study were of Analytical Grade (Merck). Standards chrysophanol, emodin and gallic acid were procured from Sigma Aldrich, Bangalore.

\section{Preliminary phytochemical analysis}

The preliminary phytochemical tests were carried out to check the presence or absence of steroids, triterpenes, flavonoids, alkaloids, coumarins, quinones, anthraquinones, glycosides, saponins, proteins, phenols and tannins as per the standard test methods. ${ }^{5}$

\section{Physicochemical parameters}

The drug was analyzed for loss on drying at $105^{\circ} \mathrm{C}$, total ash, acid insoluble ash, water soluble extractive, ethanol soluble extractive and $\mathrm{pH}$ as per the PLIM guidelines. ${ }^{6}$ Alkaloid content was determined by soaking $10 \mathrm{~g}$ of TVKC with $100 \mathrm{ml}$ of $5 \%$ acetic acid solution for $24 \mathrm{hrs}$., filtered, $\mathrm{pH}$ was altered to 8 by adding $\mathrm{KOH}$ solution and extracted with chloroform. The process was repeated for complete extraction. Finally the chloroform was evaporated and the total alkaloid extracted was calculated.

\section{Preparation of extracts}

One gram of TVKC drug was extracted successively with hexane, chloroform, ethanol and made up to $10 \mathrm{ml}$ in standard flasks separately for qualitative TLC and finger printing. Similarly one gram of TVKC drug was extracted directly with ethanol and made up to $10 \mathrm{ml}$ in a standard flask for quantitative estimation of gallic acid. In the same manner, one gram of TVKC drug was added with $25 \mathrm{ml}$ of water, boiled to one fourth, filtered and freed from moisture. Then extracted with ethanol and made up to $10 \mathrm{ml}$ in a standard flask.

\section{Preparation of standards}

$10 \mathrm{mg}$ of each of chrysophanol, emodin and gallic acid was dissolved in ethanol and made upto $10 \mathrm{ml}$ in standard flasks. The stock gallic acid standard was diluted further by taking $1 \mathrm{ml}$ and making up to $10 \mathrm{ml}$ in ethanol.

\section{Derivatizing agent}

The ethanolic potassium hydroxide ( $10 \%$ solution) was used as derivatizing agent which is specific reagent for anthraquinones.

\section{HPTLC instrument}

For developing the TLC plate, CAMAG's twin chamber was used. For the application of the extract, Linomat IV (CAMAG, Muttenz, Switzerland) applicator was used. Aluminium plate precoated with silica gel $60 \mathrm{~F}_{254}$ of $0.2 \mathrm{~mm}$ thickness (Merck) was used as TLC plate. For qualitative and quantitative scanning, CAMAG's scanner 030618 attached with WINCATS software were used. For photo documentation at UV $254 \mathrm{~nm}, 366 \mathrm{~nm}$ and in visible lights after dipping in vanillinsulphuric acid reagent followed by heating in an air circulated oven till the development of colored spots, CAMAG's visualizer was used.

\section{TLC identification}

$5 \mu \mathrm{l}$ of chrysophanol, emodin and $10 \mu \mathrm{l}$ of successive hexane, chloroform and ethanol extracts of TVKC were applied on a TLC aluminium plate $(10 \mathrm{~cm} \mathrm{x} 10 \mathrm{~cm})$ precoated with Silicagel $60 \mathrm{~F}_{254}$ of 0.2 $\mathrm{mm}$ thickness as $10 \mathrm{~mm}$ bands. The plate was developed in toluene:ethyl acetate:formic acid $(8: 1.5: 0.5, v / v / v)$ up to a height of $8 \mathrm{~cm}$ from the point of application in a presaturated twin trough chamber. The plate was dried and viewed under UV $254 \mathrm{~nm}, 366 \mathrm{~nm}$ and the respective images were captured using the visualizer. Then the plate was dipped in vanillin sulphuric acid reagent, heated at $105^{\circ} \mathrm{C}$ till the appearance of coloured spots which was also captured and documented as above.

\section{HPTLC finger printing}

Both the above TLC plates were scanned under UV $254 \mathrm{~nm}$ using deuterium lamp in the absorbance/reflectance mode. The finger print profiles of emodin, cryshophanol, hexane, successive chloroform and successive ethanol extracts of TVKC and the 3D chromatogram was documented.

\section{Quantitative estimation of gallic acid}

1 to $6 \mu \mathrm{l}$ of TVKC ethanol extracts were applied on a TLC aluminium plate $(20 \mathrm{~cm} \times 10 \mathrm{~cm})$ precoated with Silicagel $60 \mathrm{~F}_{254}$ of $0.2 \mathrm{~mm}$ thickness as $8 \mathrm{~mm}$ bands in the tracks $1,2,3,10,11$ and 12 . The gallic acid standard was applied on tracks 4 to 9 with the volumes of 1,2 , 4, 6, 8 and $10 \mu \mathrm{l}$. The plate was developed using the mobile phase, toluene:ethyl acetate:formic acid (3.5:3.5:0.5, $v / v / v)$. The developed plate was scanned densitometrically under UV $254 \mathrm{~nm}$ in quantitative mode using deuterium lamp.

\section{Heavy metal analysis}

The lead, cadmium, arsenic and mercury are considered as heavy metals and their concentration in the drug were estimated using Inductively Coupled Plasma - Optical Emission Spectroscopy (ICP-OES) by following the methods of AOAC $20^{\text {th }}$ Edition.

\section{Pesticide residue analysis}

Pesticide residue was analyzed using GC-MS (Agilent-7890 A, MS $5975)$ with DB $5 \mathrm{MS}$ column of $30 \mathrm{~m} \times 0.25 \mathrm{~mm}$ ID $\times 0.25 \mathrm{um}$ film thickness. $1 \mu \mathrm{l}$ was injected at a injection temperature of $150^{\circ} \mathrm{C}$ and $1 \mathrm{ml} / \mathrm{min}$ flow rate was maintained. Helium gas of $99.9995 \%$ purity was the carrier gas. The ion source was Electron Impact in the MS and the mass from 50 to 550 was scanned at a fixed electron energy of $-70 \mathrm{eV}$.

\section{Microbial load and pathogens}

Enterobacteriacea, E. coli, Salmonella spp. Pseudomonas aeruginosa, Staphylococcus aureus, total bacterial count and total fungal count were determined as per the WHO methods.?

\section{Aflatoxin analysis}

For aflatoxin analysis was carried out in HPLC (Agilent-1260 Infinity System) with - fluorescence detector and C-18 (Zorbax Eclipse Plus) column of $4.6 \mathrm{~mm} \times 150 \mathrm{~mm} \times 5 \mu \mathrm{m}$ inner diameter. Injection volume was $20 \mu \mathrm{l}$. Eluted the column isocratically with 1:1 mixture of methanol and water containing $238 \mathrm{mg}$ of $\mathrm{KBr}$ and $700 \mu \mathrm{l}$ of $4 \mathrm{M} \mathrm{HNO}_{3}$ in one litre of water. The hold time was $12 \mathrm{~min}$. and the flow rate was $1 \mathrm{ml} / \mathrm{min}$. KOBRA cell was used for electrochemical derivatization.

\section{RESULTS}

\section{Preliminary phytochemical analysis}

The preliminary phytochemical tests showed the presence of steroids, triterpenes, flavonoids, alkaloids, coumarins, quinones, anthraquinones, glycosides, proteins, phenols and tannins.

\section{Physicochemical parameters}

The physicochemical parameters of TVKC is shown in Figure 2. The mean calculated value of loss on drying was $11.032 \%$; total ash value 
was arrived as $4.053 \%$; acid insoluble ash was $0.240 \%$; water soluble extractive was calculated as $12.765 \%$; the ethanol soluble extractive was determined as $33.130 \%$; $\mathrm{pH}$ value of $10 \%$ solution was measured as 6.37 .

\section{TLC identification}

The TLC photodocumentation of successive hexane, chloroform and ethanol along with emodin and chrysophanol under UV $254 \mathrm{~nm}$,
$366 \mathrm{~nm}$ and after dipping in alcoholic $\mathrm{KOH}$ is shown in Figure 3. The HPTLC finger print profile of successive hexane (A), chloroform (B), ethanol (C) extracts separated with the solvent system of toluene:ethyl acetate:formic acid (8:1.5:0.5, $v / v / v)$ and the total ethanol extract (D) separated with the solvent system of toluene : ethyl acetate : formic acid (3.5:3.5:0.5, $v / v / v)$ are shown in Figure 4. The TLC chromatogram developed for the quantification of gallic acid in total ethanol extract is shown in Figure 5. The linear regression curve obtained for the standard gallic acid is produced in Figure 6.

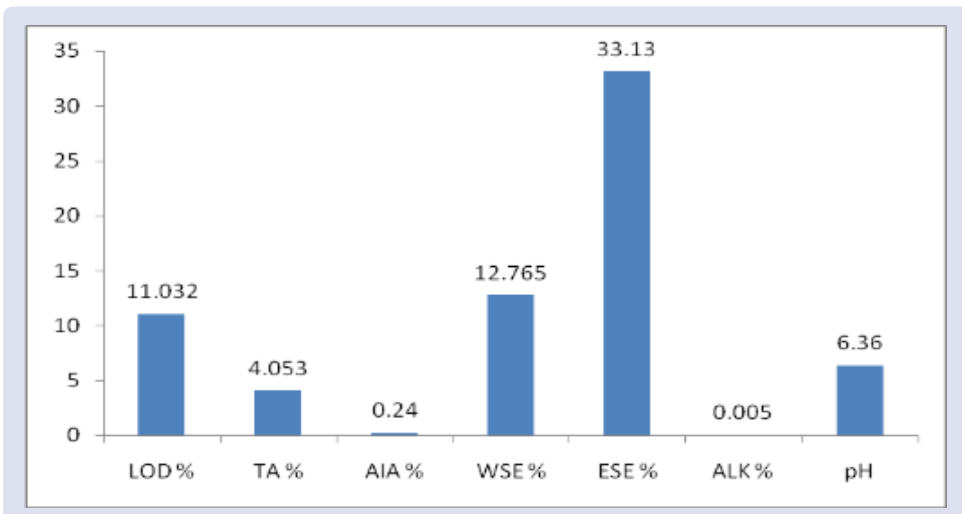

Figure 2: Graphical representation of physico-chemical values of TVKC (LOD: Loss on drying at $105^{\circ} \mathrm{C}$; TA: Total ash; AIA: Acid insoluble ash; WSE: Water soluble extractive; ESE: Ethanol soluble extractive; ALK: Alkaloid content; pH: $\mathrm{pH}$ of $10 \%$ solution).

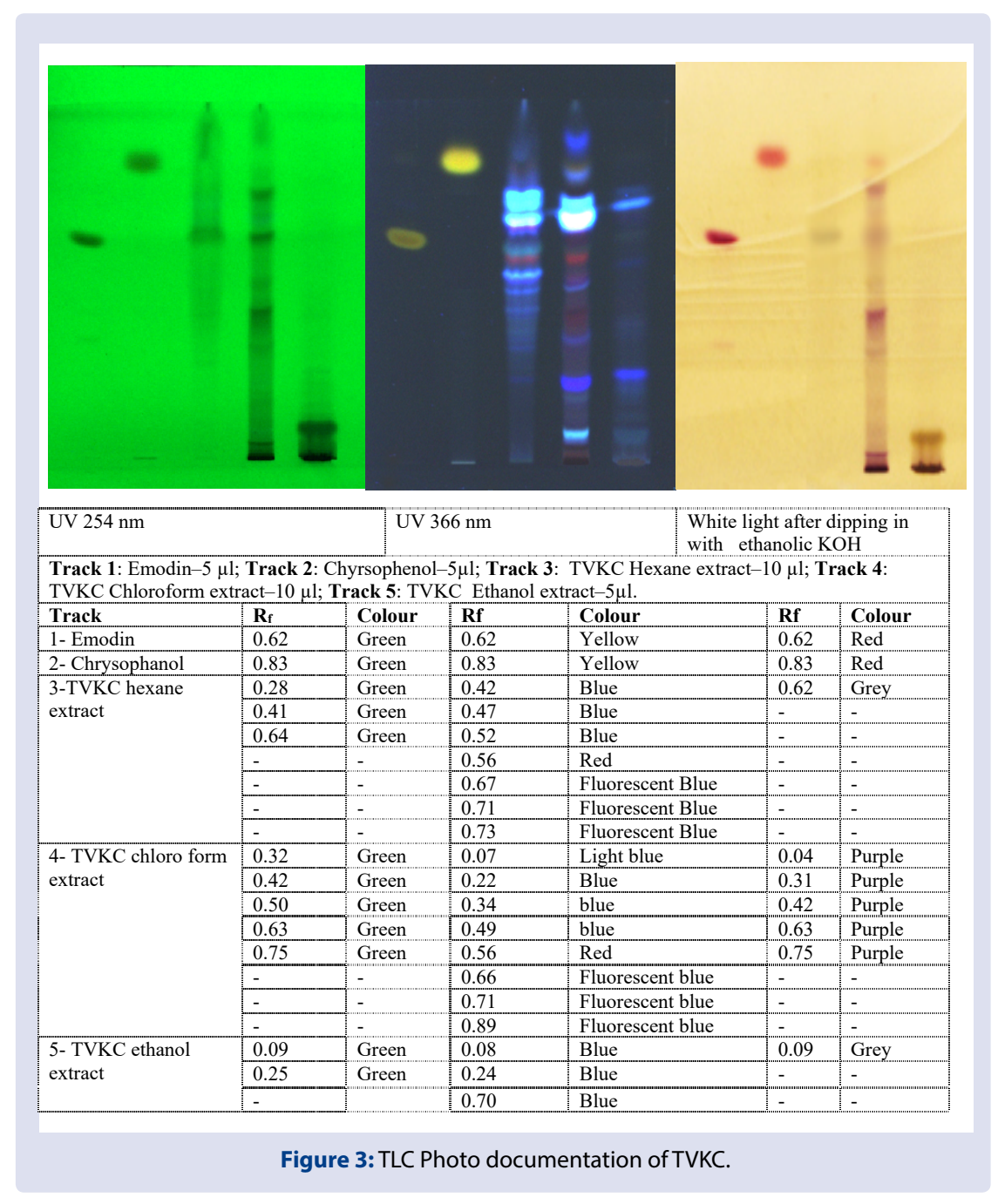



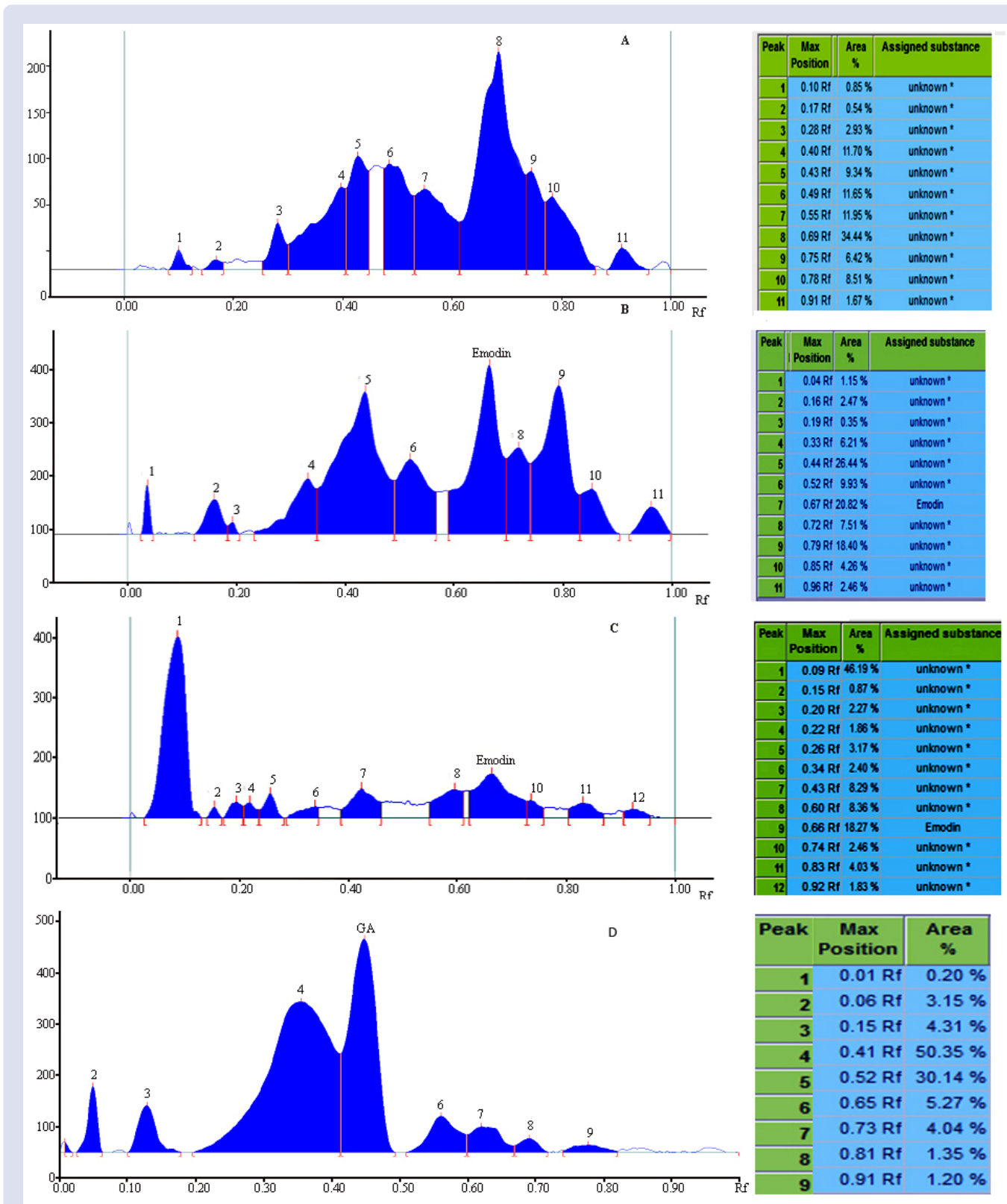

\begin{tabular}{|r|r|r|}
\hline Peak & $\begin{array}{c}\text { Max } \\
\text { Position }\end{array}$ & $\begin{array}{c}\text { Area } \\
\%\end{array}$ \\
\hline $\mathbf{1}$ & $0.01 \mathrm{Rf}$ & $0.20 \%$ \\
\hline $\mathbf{2}$ & $0.06 \mathrm{Rf}$ & $3.15 \%$ \\
\hline $\mathbf{3}$ & $0.15 \mathrm{Rf}$ & $4.31 \%$ \\
\hline $\mathbf{4}$ & $0.41 \mathrm{Rf}$ & $50.35 \%$ \\
\hline $\mathbf{5}$ & $0.52 \mathrm{Rf}$ & $30.14 \%$ \\
\hline $\mathbf{6}$ & $0.65 \mathrm{Rf}$ & $5.27 \%$ \\
\hline $\mathbf{7}$ & $0.73 \mathrm{Rf}$ & $4.04 \%$ \\
\hline $\mathbf{8}$ & $0.81 \mathrm{Rf}$ & $1.35 \%$ \\
\hline $\mathbf{9}$ & $0.91 \mathrm{Rf}$ & $1.20 \%$ \\
\hline
\end{tabular}

Figure 4: Finger print profile of successive hexane (A), chloroform (B), ethanol (C) and total ethanol (D) extracts.

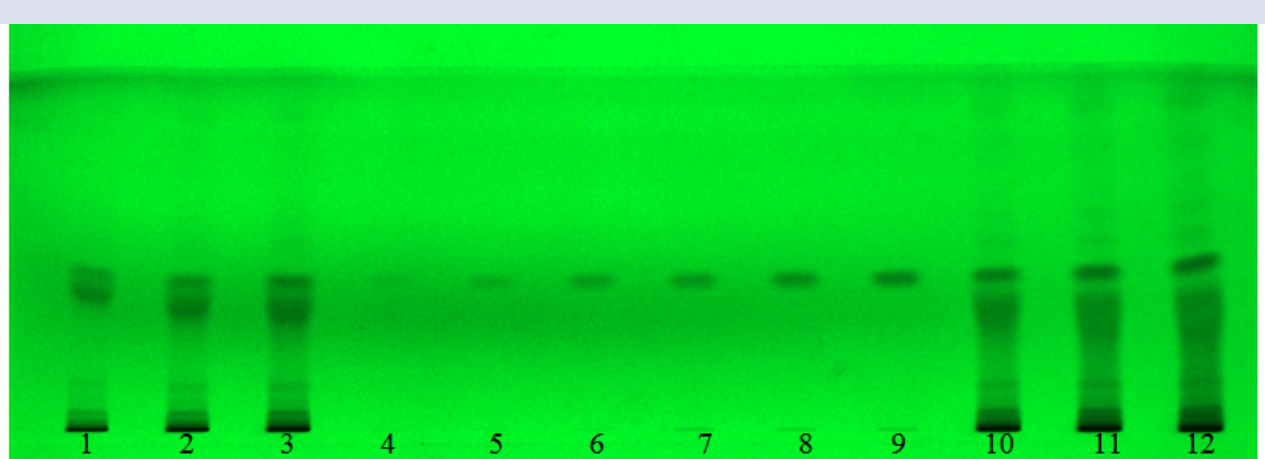

Tracks 1 to 3 and 10 to 12 - TVKC extract; Tracks 4 to 9 - Gallic acid standard

Figure 5: TLC chromatogram developed for the quantification of gallic acid in total ethanol extract. 


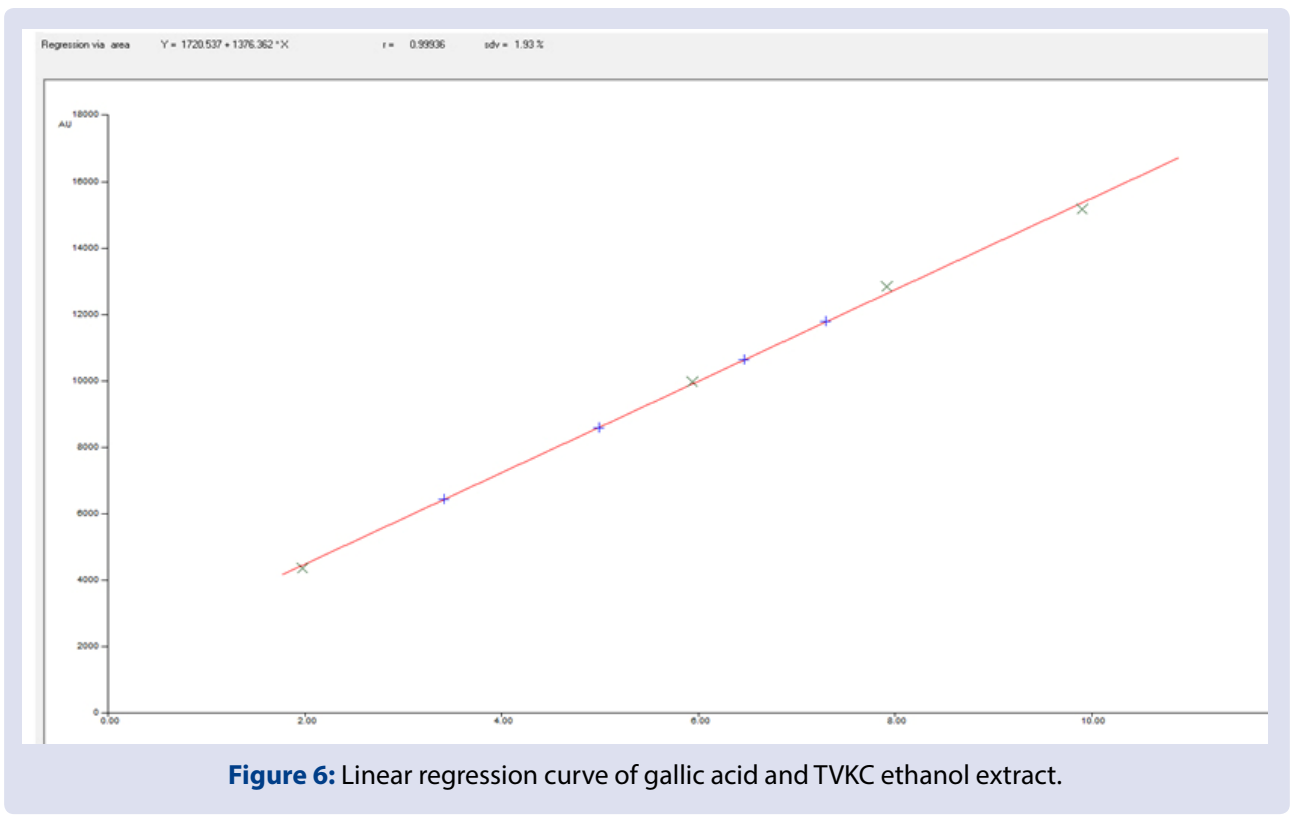

\section{HPTLC finger printing}

The HPTLC finger print profile of hexane extract showed a total of 11 peaks in which the peak at $\mathrm{R}_{\mathrm{f}} 0.69(34.44 \%), 0.59$ (11.95\%), 0.55 (11.65\%), 0.40 (11.70\%), 0.43 (9.34\%), 0.78 (8.51\%) and 0.65 (6.42\%) were the major and all other peaks were minor. In the HPTLC finger print profile of chloroform extract also, there were 11 peaks in total in which the peaks at $\mathrm{R}_{\mathrm{f}} 0.44$ (26.44\%), 0.67 (20.82\%), 0.79 (18.40\%), $0.52(9.93 \%)$ and $0.72(7.51 \%)$ were the major peaks and all other peaks were minor peaks. In the HPTLC finger print profile of ethanol extract, there were 12 number of peaks separated but the major peak appeared at $\mathrm{R}_{\mathrm{f}} 0.09(46.19 \%), 0.66(18.27 \%), 0.43(8.29 \%)$ and $0.60(8.36 \%)$ and all other peaks were minor peaks. The $3 \mathrm{D}$ chromatogram confirmed the presence of emodin in all the extracts as distinct peaks whereas presence of chrysophanol in chloroform as a minor peak.

\section{Quantification of gallic acid}

The linear regression curve for gallic acid $\left(\mathrm{Y}=1720.532+1376.362_{x} \mathrm{X}\right)$ was obtained for the concentration range 0.1 to $1.0 \mu \mathrm{g}$ with standard deviation of $1.93 \%$ and the value of correlation coefficient was 0.99936 showing the best peak purity. The percentage of gallic acid was determined as $1.61 \%$. The limit of detection was $0.0046 \mu \mathrm{g}$ and the limit of quantification was $0.014 \mu \mathrm{g}$.

\section{Heavy metal analysis}

The heavy metals, viz., lead, cadmium mercury and arsenic were lower than the limit of quantifications, the LOQ of which are 5, 0.2, 1 and 1 ppm respectively.

\section{Pesticide residue analysis}

The organo phosphorus pesticides and organo chloro pesticides such as phorate, fenitrothion, phorate sulfone, fenthion chlorfenvinphos fenthion sulfone, fenthion sulfoxide, ethion, $\beta$-BHC, $\gamma$-BHC, $\delta$-BHC, $o, \rho^{\prime}$-DDE $\rho, \rho^{\prime}$-DDE, $o, \rho^{\prime}$-DDD, $\rho, \rho^{\prime}$-DDD, $\rho, \rho^{\prime}$-DDT and $o, \rho^{\prime}$-DDT were found to be below the limit of quantification (LOQ $0.01 \mathrm{ppm}$ ).

\section{Microbial load and pathogens}

The Enterobacteriaceae, Escheria coli, Salmonella spp., Staphylococcus aureus were found to be absent in the drug, the total bacterial count and total fungal count were within the permissible limit for internal use as per WHO.

\section{Aflatoxin analysis}

The aflatoxin $B_{1}, G_{1}, B_{2}$ and $G_{2}$ were found to be below the limit of quantification (LOQ $0.1 \mathrm{ppm}$ ).

\section{DISCUSSION}

The presence of phytochemicals such as steroids, triterpenes, flavonoids, alkaloids, coumarins, quinones, anthraquinones, glycosides, proteins, phenols and tannins would enhance the therapeutic efficacy of the drug. The C. auriculata seed is rich in fatty acids, sterols, ${ }^{8}$ many flavonoids and flavonoid glycosides. ${ }^{9}$ Flavonoids are known for their antioxidant, antibacterial and anticancer activities..$^{10}$ The alkaloids, diaboline and its acetate, ${ }^{11}$ brucine ${ }^{12}$ were reported from $S$. potatorum seeds. Many phenols reported in $T$. chebula include ellagic acid, punicalagin, chebulanin, neochebulinic acid, chebulinic acid, 1,2,3,4,6-penta- $O$-galloyl-H-D-glucose, 1,6-di$O$-galloyl-D-glucose, casuarinin, 3,4,6-tri-O-galloyl-D-glucose and terchebulin..$^{13-15}$ These phenols are very good antibacterial agents and they facilitate in extending the shelf life of the drug. ${ }^{16}$

The $11.032 \%$ of loss on drying indicates that the moisture content is slightly high which may be due to the fixed oil present in the $C$. auriculata seed and the resinous matter present in the T. chebula fruit rind. The total ash value of $4.053 \%$ represents the presence of lesser inorganic minerals in the TVKC. Similarly, the acid insoluble ash was very less $0.240 \%$ which infers the absence of siliceous matter. The water soluble extractive was calculated as $12.765 \%$ and the ethanol soluble extractive was determined as $33.130 \%$. When compared to water soluble extractive, the ethanol soluble extractive is higher indicating the presence of high polar compounds viz., glycosides, sugars, tannins, saponins, alkaloids, etc. The total alkaloid content was determined as $0.005 \%$ which is very less and is not detectable by Dragendorff reagent on TLC plate. The $\mathrm{pH}$ value of 6.37 , indicates the acidic nature which could reduce the opportunity for microbial attack thereby extending the shelf life of TVKC. With the standardized the physico-chemical parameters, the drug could be subjected to routine analysis quality control in bulk production in batches ${ }^{17}$ and serves as the prerequisite for toxicity ${ }^{18}$ and clinical ${ }^{19}$ evaluations.

The TLC plate under UV $254 \mathrm{~nm}$ showed the presence of spot with the $\mathrm{R}_{\mathrm{f}}$ of emodin in hexane, chloroform and ethanol extracts where as the presence of spot with the $\mathrm{R}_{\mathrm{f}}$ of chrosophanol was not visible. However, the finger print profile under UV $254 \mathrm{~nm}$, the peak present in 
hexane extract did not match with the peak of emodin and identified as a unknown peak, ie., emodin was not present in hexane extract and very very less in ethanol extract. The plate under UV $366 \mathrm{~nm}$ showed the presence of chrysophanol in hexane and chloroform extracts. The derivatized plate showed the presence of emodin in chloroform only and chrysophanol in none of the extract. The successive ethanol extract showed the presence of high polar compounds. Since emodin and chrysophanol were present in traces, the estimation of these anthraquinones was not done. These two anthraquinones were from the seed of C. auriculata and the gallic acid was from the T. chebula. Though the presence of gallic acid was not qualitatively run for TLC, it was quantitatively estimated in the drug TVKC. The gallic acid has been reported for anti-inflammatory ${ }^{20}$ cardioprotective effects in diabetes induced myocardial dysfunction, ${ }^{21}$ antibacterial, ${ }^{22}$ cytotoxic activity, ${ }^{23}$ antioxidant ${ }^{24}$ and anti-diabetic ${ }^{24,25}$ activities. As the content of gallic acid as determined by HPTLC is $1.61 \%(w / w)$, TVKC will exhibit the similar activities of gallic acid. The standardization of any herbal formulation would be complete only if done along with ingredients and chemical markers. ${ }^{26}$ The quantification of chemical markers for the standardization of herbal drugs using HPTLC/HPLC has been reported. ${ }^{27,28}$

The heavy metals, viz., lead, cadmium mercury and arsenic were well within the WHO prescribed permissible limits 10, 0.3, 1 and $3 \mathrm{ppm}$ respectively. The trepidation of herbal drug consumers with respect to heavy metal poisoning ${ }^{29,30}$ is ruled out and the drug is safe. As the aflatoxin $B_{1}, G_{1}(<0.5 \mathrm{ppm}), B_{2}$ and $G_{2}(<0.1 \mathrm{ppm})$ were found to be below the limit of and the drug could be administered internally. The organo phosphorus pesticides and organo chloro pesticides were also found to be below the limit of quantification indicating the collection of wild plants as per good collection practices. The drug was free from Enterobacteriaceae, Escheria coli, Salmonella spp., Staphylococcus aureus and the total bacterial count and total fungal count were within the safety limit for internal medicine.

\section{CONCLUSION}

The antidiabetic siddha formulation TVKC has been standardized for physicochemical parameters, screened the presence of different secondary metabolites, showed the presence of quinones \& polyphenol by TLC and estimated the gallic acid. Also the drug was ensured for the absence of heavy metals, pesticide residues, microbial load and aflatoxins. These standardization parameters could be considered as a reference standard of this drug for quality control assessment in future.

\section{ACKNOWLEDGEMENT}

The authors are thankful to The Director General, CCRS, The Assistant Director I/c, Siddha Central Research Institute for facilities and support and Dr. Sasikala Ethirajulu,, Research Officer (Pharmacognosy) for authentication of ingredients.

\section{CONFLICTS OF INTEREST}

None.

\section{REFERENCES}

1. Anonymous. Theraiyar Kudineer (Moolamum Vuraiyum), $2^{\text {nd }}$ edition. New Delhi: Central Council for Research in Ayurveda and Siddha. 1996;41-2.

2. Anonymous. The ayurvedic pharmacopoeia of India, Part I, Vol. I. New Delhi: Department of AYUSH, ministry of health and family welfare, government of India. pp: 62

3. Anonymous. The ayurvedic pharmacopoeia of India, Part I, Vol. IV. New Delhi: Department of AYUSH, ministry of health and family welfare, government of India; pp: 48.
4. Anonymous. The Siddha Formulary of India, Part I, $1^{\text {st }}$ edition. New Delhi Department of $\mathrm{AYUSH}$, ministry of health \& family welfare, government of India; pp: 232.

5. Harborne JB. Phytochemical methods. Jackman H, Editor. London; 1973;70.

6. Lohar DR. Pharmacopoeial laboratory for Indian medicine. Department of Ayurvedha, yoga and Naturopathy, Siddha, Unani and Homoeopathy (AYUSH), ministry of health and family welfare. New Delhi. 2011; pp: 20.

7. Anonymous. Quality control methods for medicinal plant materials, world health organisation, Geneva, 1998.

8. Raj JY, Peter MPJ, Joy V. Chemical compounds investigation of Cassia auriculata seeds: A potential folklore medicinal plant. Asian J Plant Sci Res. 2012;2:187-92.

9. Zhang Y, Nakamura S, Nakashima S, Wang T, Yoshikawa M, Matsuda H. Chemical structures of constituents from the seeds of Cassia auriculata. Tetrahedron. 2015;71:6727-32

10. Ren W, Qiao Z, Wang H, Zhu L, Zhang L. Flavonoids: Promising anticancer agents. Med Res Rev. 2003;23(4):519-34.

11. Anonymous. Wealth of India. Raw Materials: Sp-W. Vol. 10, New Delhi: Publications and Information Directorate, CSIR, 1976, pp: 66-7.

12. Trease and Evans. Pharmacognosy. $12^{\text {th }}$ edn. London: Balliere-Tindall, 1983, pp: 36.

13. Bruneton J. Pharmacognosy, phytochemistry, medicinal plants. Paris, France: Laviosier Publishing. 1995;333.

14. Chevallier A. The encyclopedia of medicinal plants. New York: DK Publishing. 1996;336.

15. Juang LJ, Sheu SJ, Lin TC. Determination of hydrolyzable tannins in the fruit of Terminalia chebula Retz. by high-performance liquid chromatography and capillary electrophoresis. J Sep Sci. 2004;27:718-24.

16. Chung KT, Wong TY, Wei Cl, Huang YW, Lin Y. Tannins and human health: A review. Crit Rev Food Sci Nutr. 1998;38:421-64.

17. Naikodi MAR, Waheed MA, Shareef MA, Ahmad M. Standardization of Unan drug - Myristica fragrans Houtt. (Javetri) - with modern analytical techniques. Pharmaceutical Methods. 2011;2:76-82.

18. Sakulpanich A, Chewchinda S, Sithisam P, Gritsanapan W. Standardization and toxicity evaluation of Cassia fistula pod pulp extract for alternative source of herbal laxative drug. Phcog J. 2012;28:6-12.

19. Bonati A. How and why should we standardize phytopharmaceutical drugs for clinical validation? J Ethnopharmacol. 1991;34:195-7.

20. Kores BH, Van den Berg AJ, Quarles van Ufford HC, van Dijk H, Labadie RP Anti-inflammatory activity of gallic acid. Planta Medica. 1993;58:499-504.

21. Patel SS, Goyal RK. Cardioprotective effects of gallic acid in diabetes-induced myocardial dysfunction in rats. Pharmacog Res. 2011;3:239-45.

22. Al-Zahrani SHM. Antibacterial activities of gallic acid and gallic acid methyl ester on methicillin-resistant Staphylococcus aureus. J American Sci. 2012;8:7-12.

23. Schuck AG, Weisburg JH, Esan H, Robin EF, Bersson AR, Weitschner JR, et al. Cytotoxic and proapoptotic activities of gallic acid to human oral cancer HSC-2 cells. Oxid Antioxid Med Sci. 2013;2:265-74.

24. Adefegha SA Oboh G, Ejakpovi II, Oyeleye SI. Antioxidant and antidiabetic effects of gallic acid and protocatechuic acids: A structure - function perspective. Comp Clin Pathol. 2015;24:1579.

25. Purbowatiningrum, Ngadiwiyana, Ismiyarto, Fachriyah E, Eviana I, Eldiana O, et al. Antidiabetic activity from gallic acid encapsulated nanochitosan. IOP Conf Ser Mater Sci Eng. 2017;172:012042.

26. Ahmad W, Zaidi SMA, Mujeeb M, Ansari SH, Ahmad S. HPLC and HPTLC methods by design for quantitative characterization and in vitro anti-oxidant activity of polyherbal formulation containing Rheum emodi. J Chromatogr Sci. 2013;52:911-8

27. Mishra A, Mishra AK, Tiwari OP, Jha S. HPLC analysis and standardization of Brahmi vati - an Ayurvedic poly-herbal formulation. J Young Pharm. 2013;5:7782.

28. Baragi CU, Baragi CP, Vyas KM, Shukla VJ. Standardization and quality control parameters of Dashanga Kwatha Ghana tablet: An Ayurvedic formulation. Int $J$ Ayurveda Res. 2011;2:42-7.

29. Pilarczyk R, Wojcik J, Czerniak P, Sablik P, Pilarczyk B, Tomza-Marciniak A. Concentrations of toxic heavy metals and trace elements in raw milk of Simmental and Holstein-Friesian cows from organic farm. Environ Monit Assess . 013;185:8383-92.

30. Mishra S, Dwivedi SP, Singh RB. A review on epigenetic effect of heavy meta carcinogens on human health. The Open Nutraceuticals Journal. 2010;3:18893. 


\section{GRAPHICAL ABSTRACT}

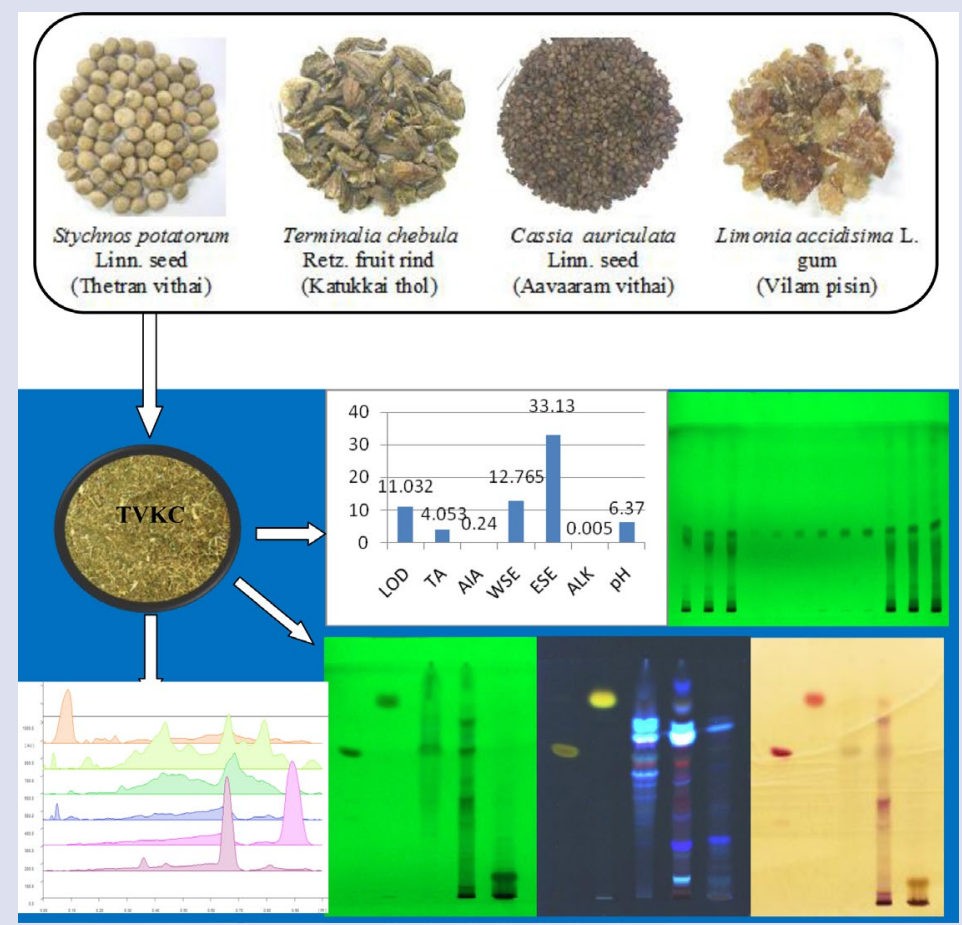

\section{ABOUT AUTHORS}

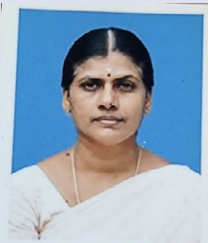

Dr. P. Elankani MD(S) is presently working as Research Officer (Siddha)Sci-2 at Siddha Clinical Research Unit, (Central Council for Research in Siddha, Ministry of AYUSH, Govt. of India). Research area: Validation of Siddha drugs by conducting clinical trial, Standardization of the trial drug.

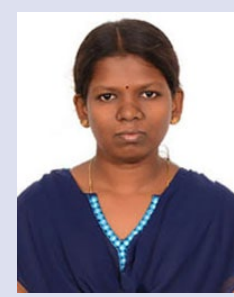

Mrs. S. Murugammal is presently working as Lab Technician (Chemistry) at Siddha Central Research Institute (Central Council for Research in Siddha, Ministry of AYUSH, Govt. of India). Research field: Standardization of Siddha formulation, isolation of secondary metabolites, method development and validation for quantification of chemical markers by HPTLC.

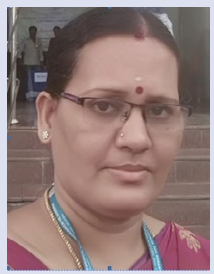

Dr. R. Shakila is presently working as Research Officer (Chemistry) at Siddha Central Research Institute (Central Council for Research in Siddha, Ministry of AYUSH, Govt. of India). Research field: Standardization of Siddha formulation, isolation of secondary metabolites, method development and validation for quantification of chemical markers by different chromatographic techniques.

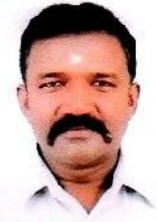

Dr M. Pitchiah Kumar M.D(S) is presently working as State Licensing Authority for Indian medicine, AAGHIM Campus Annex, Arumbakkam, Chennai, Tamilnadu, India. Experience: He has 18 years of teaching experience and has guided Post graduate students of Govt. Siddha Medical College, Chennai. 
Dr. N. KABILAN, MD (S), Ph.D., is presently working as Professor \& Head in the Department of Siddha at The Tamilnadu Dr. M.G.R. Medical University, 69, Anna Salai, Guindy, Chennai-600 032. He has an experience in Teaching, Research and administrative area.

Cite this article: Elankani P, Murugammal S, Shakila R, Pitchiahkumar M, Kabilan N. Chemical Standardization of Thetran Vithai Kutinir Chooranam - An Antidiabetic Siddha Polyherbal Formulation. Pharmacog J. 2019;11(5):1106-13. 